\title{
半没水上部斜面ケーソン式防波堤への 性能設計の適用について \\ STUDY ABOUT APPLICATION OF PERFORMANCE-BASED DESIGN TO HALF-SUBMERGED SLOPING TOP CAISSON BREAKWATER
}

\author{
興野俊也 $^{1} \cdot$ 安田勝則 $^{1} \cdot$ 赤石沢総光 $^{2}$ ・ \\ 長舩徹 ${ }^{3}$ ・阿部光信 ${ }^{3}$ \\ Toshiya KYONO, Katsunori YASUDA, Nobuhiko AKAISIZAWA, \\ Toru OSAFUNE and Mitsunobu ABE
${ }^{1}$ 正会員 東京電力株式会社電力技術研究所土木グループ（テ230-8510 神奈川県横浜市鶴見区江ヶ崎町 4 番 1 号)
${ }^{2}$ 正会員 修(工) 東京電力株式会社電力技術研究所土木グループ（同上） \\ ${ }^{3}$ 正会員 東電設計株式会社第二士木本部港湾・海岸部（T110-0015 東京都台東区東上野三丁目 3-3）
}

\begin{abstract}
The Performance-Based Design can be used as a method of rationally determining the section of a breakwater. We have already proposed the designing method of the breakwater for two failure modes of sliding and settlement as well as its safety evaluation method. In this paper, the above methods are applied to a half-submerged sloping top caisson breakwater and the stability against wave action is studied, considering the applicability of safety indexes and the difference of the structural type. As a result, it is shown that there is the difference between each section designed by the amount of expected deformation, function loss probability, and life-cycle cost, for a half-submerged sloping top caisson breakwater. This result is different from that for a vertical caisson breakwater. Also, it is found that it is important to control the function loss probability, which is here defined as the occurrence probability of the breakwater's fatal damage.
\end{abstract}

Key Words : performance-based design, reliability design method, sliding distance, settlement rate, function loss probability, half-submerged sloping top caisson breakwater

\section{1. まえがき}

近年の土木設備のコスト縮減と安全に対する信頼性確 保の観点から「性能設計」が注目されている。これは, 構造物の必要性能に基づいて月標とする要求性能を明確 にし，構造断面の保有性能がその要求性能を満足するこ とを直接照査する設計体系である. 港湾施設としての防 波堤に必要な機能は, 利用する船舶が安全に航行, 係留, 荷役できる水域を確保することにあり，その機能が維持 できれば防波堤の滑動, 沈下などの変形はある程度許容 でき, 防波堤の性能に応じた合理的な断面設計が可能と なる.

防波堤の変形を考慮した設計法については，下迫・高 橋 ${ }^{1)}$ が期待滑動量を用いる信頼性設計法を提案し，堤体 の滑動変形に対して要求性能に応じた変形量の許容值を 設定することにより合理的な堤体断面の設定が可能であ ることを示した. また, 土田・湯 ${ }^{2)}$ は, 防波堤の支持力
安定性に着目して堤体の沈下量を推定するモデルを提案 している. 一方, 著者ら ${ }^{3)}$ は, 防波堤の性能設計活用に よる設計合理化の一環として, 滑動と沈下の 2 つの破壊 モードを考慮した設計法を提案するとともに, 試設計を 通じてその安全性評価方法の適用性を明らかにした. し かしこれらの研究はいずれも直立ケーソン堤を対象と しており，その他の構造様式に対する適用性や構造様式 による安定性の相違については検討されていない.

そこで, 本論文では, 経済的な大水深部防波堤である 半没水上部斜面ケーソン堤を対象として, 著者ら ${ }^{3)}$ が提 案した堤体の滑動と沈下を考慮した設計法とその変形に 基づく安全性評価方法の適用性を検討した. さらに, 直 立ケーソン堤との比較により半没水上部斜面ケーソン堤 の変形特性, 而波安定性について評価した.

\section{2. 性能設計の半没水上部斜面ケーソン堤への適用方法}




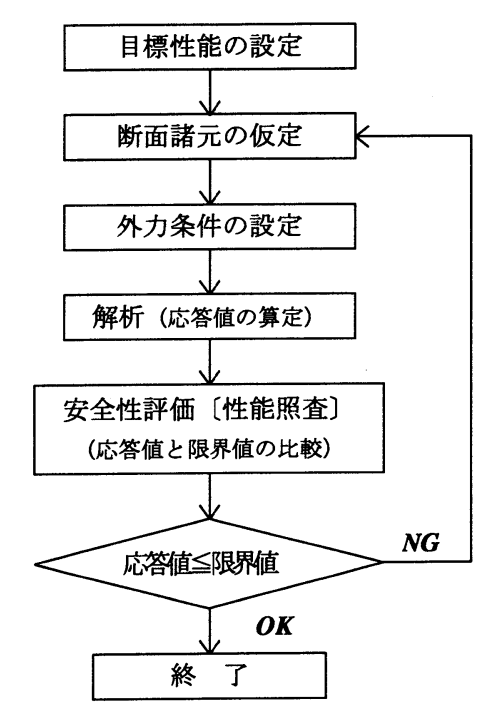

図-1 防波堤の性能設計の手順

\section{（1）性能設計の手順と目標性能の設定}

防波堤の性能設計は図一1 の手順で行う。まず，港湾 の利用状況，制約条件等に基づいて港湾および港湾施設 に必要とされる性能を明確にして防波堤の目標性能（必 要とされる性能を満たすために設計で害現しようとする 性能）を設定する. そして, 設計対象地点の気象・海象 条件，地形・地般条件，材料条件や外力条件などを設定 し，防波堤の性能の照査項目である堤体の滑動・沈下量 とその発生確率分布を各種設計条件の推定誤差, ばらつ きを考虑したモンテカルロシミュレーションにより算定 する. 求めた堤体の滑動・沈下量, 発生確率分布などの 応答值は目標性能に基づいて設定した限界值（許容值） との比較により, 保有性能を直接照査する.

表-1 は防波堤の目標性能と各性能レベルに対する滑 動量と沈下量の限界值の案をまとめたものである.ここ で, 而波性能 2 の限界值は既往の研究 ${ }^{1)}$, 3) 参考に防波 堤の機能が維持できる变形量として，耐波性能 3 の限界 值は防波堤が壊滅的な被害を受ける変形量として設定し た.

合理的な設計を行うためには，適切な安全性評価指標 と許容值を設定する必要がある. 著者ら ${ }^{3)}$ は, 滑動・沈 下量の確率分布に基づく変形量（期待滑動量, 期待沈下 量）による評価，防波堤としての機能損失の確率による 評価, ライフサイクルコスト（LCC）による評価の3つ の安全性評価指標を示すとともに, 変形量による評価で は而披性能 2 の限界值を許容值とし, 機能損失確率によ る評価では耐波性能 3 を越える変形量の発生確率を日本 の防波堤の許容破壊確率以下 $\left(1 \times 10^{-2} \text { 以下 }\right)^{4)}$ とするこ とを提案した.

\section{（2）半没水上部斜面ケーソン堤の}

\section{滑動・沈下量の算定方法}

図-2 は防波堤の滑動・沈下量の確率分布の算定フロ 一である. この方法は, 耐用期間中の高波浪の来襲頻度
防波堤の目標性能と性能レベルに対する限界值

\begin{tabular}{|c|c|c|c|}
\hline \multirow{2}{*}{ 要求性能 } & \multirow{2}{*}{ 目標性能 } & \multicolumn{2}{|c|}{ 限界値 } \\
\hline & & 滑動量 & 沈下量 \\
\hline $\begin{array}{l}\text { 港湾内の諸作業, 設 } \\
\text { 諎く影響ない }\end{array}$ & $\begin{array}{l}\text { 船舶，荷役などに影 } \\
\text { 響を及ぼす汸を波の } \\
\text { 変形がほとんどない }\end{array}$ & $0.0 \sim 0.1 \mathrm{~m}$ & $0.0 \sim 0.3 \mathrm{~m}$ \\
\hline $\begin{array}{l}\text { 港湾内の諸作業, 設 } \\
\text { 諎へ影響は軽微で } \\
\text { 運用上問題ない }\end{array}$ & $\begin{array}{l}\text { 船舶, 荷役などに影 } \\
\text { 響を及ぼす防波堤の } \\
\text { 有害な変形がない }\end{array}$ & $0.1 \sim 0.3 \mathrm{~m}$ & $0.3 \sim 0.5 \mathrm{~m}$ \\
\hline $\begin{array}{l}\text { 港湾内の諸作業に長 } \\
\text { 期的な影響を生じな } \\
\text { い }\end{array}$ & \begin{tabular}{|l|} 
港内諸施設に重大な \\
影響を及ぼす防波堤 \\
の大変形がない
\end{tabular} & $0.3 \sim 10.0 \mathrm{~m}$ & $0.5 \sim 2.0 \mathrm{~m}$ \\
\hline
\end{tabular}

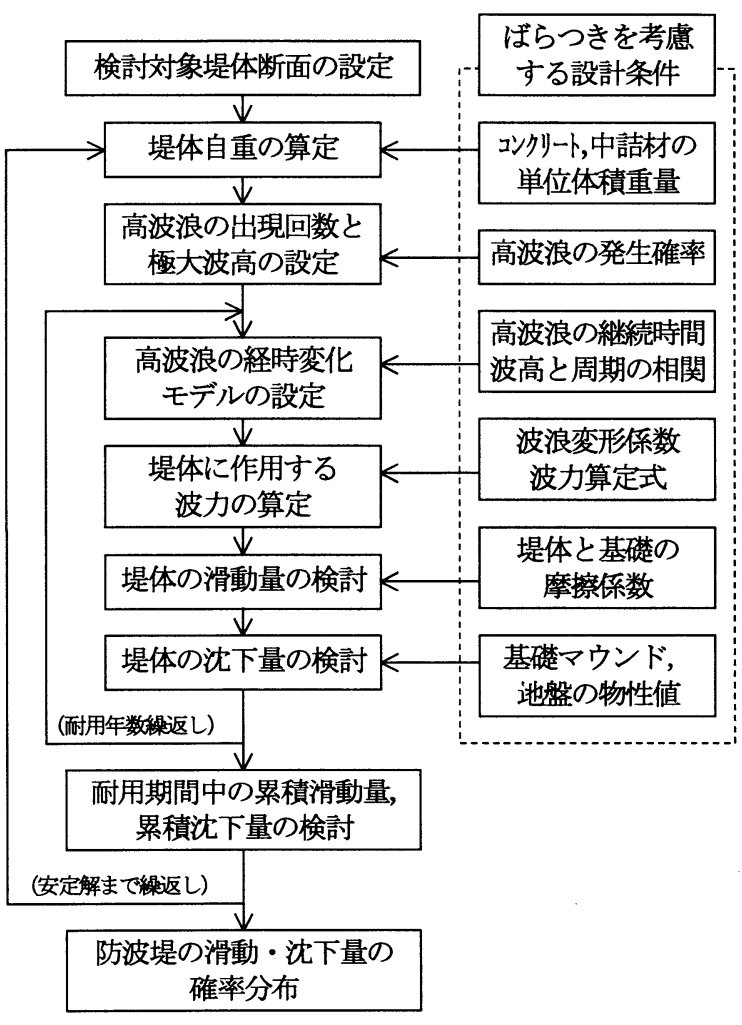

図-2 滑動・沈下量の確率分布の算定フロー

を仮定し，1 回の高波浪（時化）による滑動量・沈下量 の計算を来襲波浪回数分繰り返して, 耐用期間中の総滑 動量・総沈下量を求めるものである. 堤体に作用する高 波浪などの設計条件については，その推定誤差やばらつ きをモンテカルロシミュレーションによって考慮する.

半没水上部斜面ケーソン堤では波力の評価方法が特 徵的である. 図一 3 は細山田ら ${ }^{5)}$ が提案した半没水上部 斜面ケーソン堤の波力算定式の模式図である. 堤体に作 用する波力は, 斜面壁の効果によって, 水平波力が合田 式に比べて小さくなるとともに, 斜面壁部は鉛直方向に 堤体を押さえ込む鉛直波力が作用する. 半没水上部斜面 ケーソン堤の滑動量, 沈下量の算定にあたっては, この ような効果を考慮する必要がある.

1 波あたりの滑動量算定モデルについては, 谷本ら 7 の堤体滑動時の運動方程式に基づくモデルを用いた.す なわち, (1)式に示す堤体の加速度 $\ddot{x}_{G}$ を 2 回数值積分す ることにより堤体の変形量を求めるものである. 


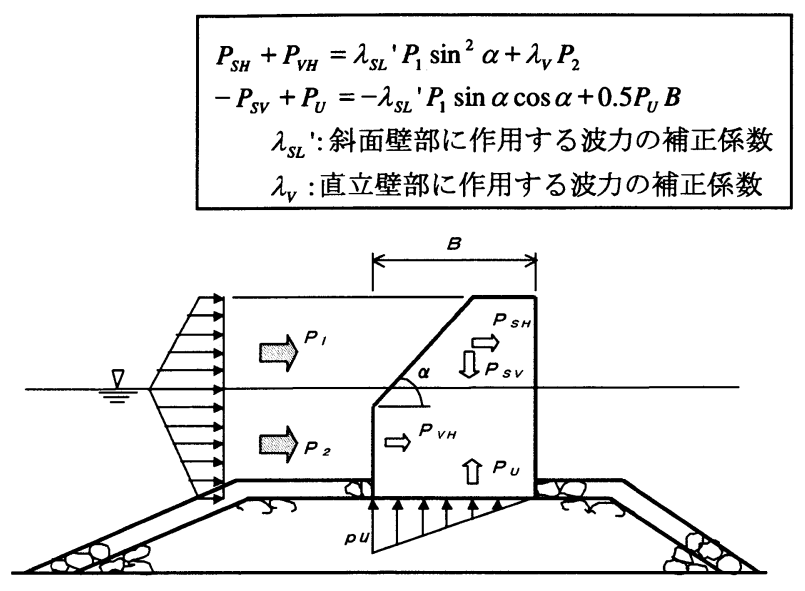

図一3 半没水上部斜面ケーソン堤の波力算定法

$\left(W / g+M_{a}\right) \ddot{x}_{G}=P-F_{R}-F_{D}$

ここで, $W$ は堤体の空中重量, $g$ は重力加速度, $M_{a}$ は 付加質量, $P$ は水平波力, $F_{R}$ は摩擦抵抗力, $F_{D}$ は流体 抵抗力である. 半没水上部斜面ケーソン堤の場合, 水平 波力 $P$ と摩擦抵抗力 $F_{R}$ がそれぞれ次式のようになる.

$$
\begin{aligned}
& P=P_{S H}+P_{V H} \\
& F_{R}=\mu\left(W+P_{S V}-P_{U}\right)
\end{aligned}
$$

ここで， $P_{S H}, P_{V H}$ はそれぞれ斜面壁部と直立壁部の水平 波力, $P_{S V}$ は斜面壁部の鉛直波力, $P_{U}$ は揚圧力, $\mu$ は堤 体と基礎の摩擦係数である.

1 波あたりの沈下量算定モデルは，土田・湯 ${ }^{2)}$ の円弧 すべり解析法に基づくモデルを用いた. すなわち，(4)式 に示す円弧すべりの回転角加速度 $\ddot{\theta}$ を 2 回数值積分する ことにより回転角度 $\Delta \theta$ を求め, (5)式にて鉛直移動量, すなわち沈下量を求めるものである.

$$
\begin{aligned}
& I \ddot{\theta}=M g \\
& S=\Delta \theta \cdot R \cdot \sin \theta
\end{aligned}
$$

ここで，I は堤体を含めた円弧すべり原点に関する円弧 すべり体の形状二次モーメント， $\boldsymbol{M}$ は円弧すべりの起 動モーメント $M_{D}$ と抵抗モーメント $M_{R}$ の差分, $g$ は重 力加速度, $R$ は円弧すべり体の半径, $S$ が沈下量である. 半没水上部斜面ケーソン堤の場合, 円弧すべりの起動モ 一メント $M_{D}$ の算定において，その作用外力に水平波力 の低減と鉛直波力を考慮する.

なお，以上の滑動量，沈下量の算定方法はいずれも 1 波あたりの変形量を対象としており，これを有義波諸元 で代表される 1 回の波群に展開するためには, 波高階級 ごとの出現波数をレーリー分布に基づいて求めることと した. また，波群の連続によって表される時化の経時変 化については, 太平洋岸の代表 3 地点における波浪観測 の高波浪データに基づいて設定した極大波高と時化の継 続時間の関係式》をを用いた。

図-4 は，細山田ら ${ }^{5)}$ が実施した半没水上部斜面ケー ソン堤の波力実験による水平波力の推定誤差の出現頻度 分布である. 図の上段が斜面壁部，下段が直立壁部で, それぞれ横軸に実験で得られた波力の計測值と波力算定
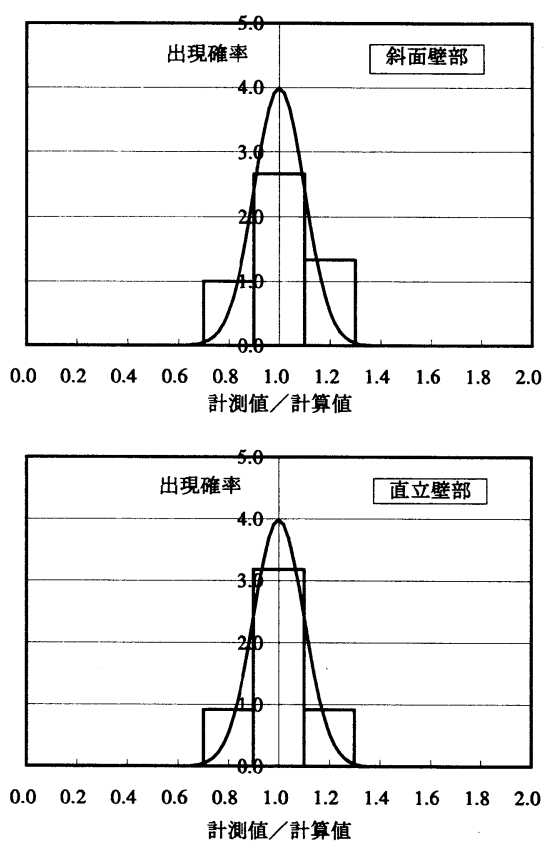

図-4 波力算定式の推定精度

式 ${ }^{5)}$ による計算値の比, 縦軸に実験での計測頻度を示し ている. 図中の曲線は合田式による波力の推定誤差とし て下迫・高橋 ${ }^{1)}$ が提案した平均的偏りが $\alpha=0.00$, 変動 倸数が $\gamma=0.10$ の正規分布である. これによれば, 半没 水上部斜面ケーソン堤の波力の推定誤差は, 斜面壁部と 直立壁部のいずれにおいてもほぼ正規分布で近似でき, その平均的偏り, 変動係数は合田式に対する值でよいも のと推察された.

\section{3. 半没水上部斜面ケーソン堤の滑動・沈下量の試計算}

以上の半没水上部斜面ケーソン堤の性能設計の適用 方法を用いて，モデル防波堤に対する滑動量，沈下量の 試計算を行った. 検討対象防波堤断面は図一 5 に示すと おりで, 設置水深は- $20.0 \mathrm{~m},-16.0 \mathrm{~m}$ の 2 タイプ, 堤体 幅は表一 2 に示す全 9 ケースとした. 設計沖波は，いず れの断面も $\left(H_{1 / 3}\right)_{o}=8.2 \mathrm{~m},\left(T_{1 / 3}\right)_{o}=14.0 \mathrm{~s}$ で, 高波浪の極 值統計分布はWeibull 分布 $(k=2.00)$, 高波浪の出現回

検討対象断面諸元

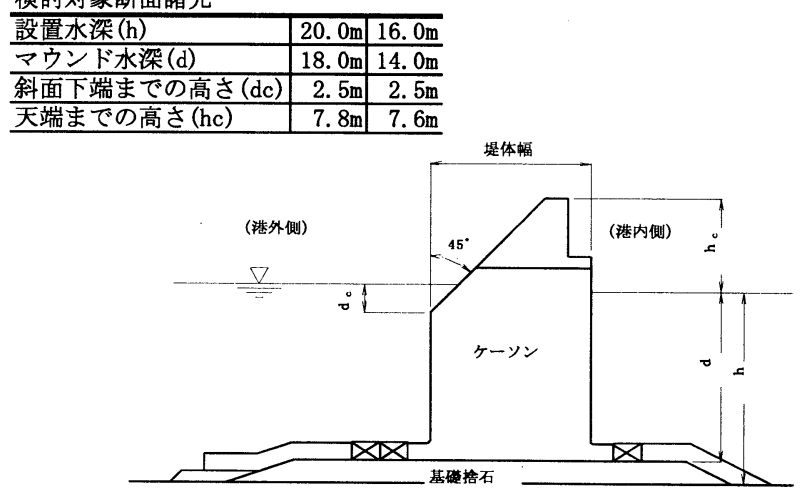

図一5 検討対象断面 
表ー2 検討ケース（堤体幅と從来設計法での安全率）

\begin{tabular}{c|c|c|c}
\multicolumn{2}{l}{ 設置水深 -20m } \\
\hline \multirow{2}{*}{ ケース } & 堤体幅 & \multicolumn{2}{|c}{ 安全率 } \\
\cline { 3 - 4 } & 滑 動 & 支持力 \\
\hline \hline $\mathrm{S} 20-1$ & $15.3 \mathrm{~m}$ & 1.35 & 1.00 \\
\hline $\mathrm{S} 20-2$ & $15.0 \mathrm{~m}$ & 1.33 & 0.95 \\
\hline $\mathrm{S} 20-3$ & $14.5 \mathrm{~m}$ & 1.29 & 0.86 \\
\hline $\mathrm{S} 20-4$ & $14.0 \mathrm{~m}$ & 1.26 & 0.77 \\
\hline
\end{tabular}

設置水深 $-16 \mathrm{~m}$

\begin{tabular}{c|c|c|c}
\hline \multirow{2}{*}{ ケース } & \multirow{2}{*}{ 堤体幅 } & \multicolumn{2}{|c}{ 安全率 } \\
\cline { 3 - 4 } & & 滑 動 & 支持力 \\
\hline \hline $\mathrm{S} 16-1$ & $15.4 \mathrm{~m}$ & 1.20 & 1.00 \\
\hline $\mathrm{S} 16-2$ & $15.0 \mathrm{~m}$ & 1.18 & 0.96 \\
\hline $\mathrm{S} 16-3$ & $14.5 \mathrm{~m}$ & 1.15 & 0.92 \\
\hline $\mathrm{S} 16-4$ & $14.0 \mathrm{~m}$ & 1.12 & 0.86 \\
\hline $\mathrm{S} 16-5$ & $13.5 \mathrm{~m}$ & 1.10 & 0.82 \\
\hline
\end{tabular}

数は 50 回（耐用期間 50 年, 1 回/年）とした. モンテカ ルロシミュレーションで考慮する設計条件のばらつき, 推定誤差の分布は著者ら ${ }^{3)}$ に従い, 試行回数は滑動量お よび沈下量の累積平均值がほぼ一定となる 2000 回とし た.

図一6および図一7は，それぞれ設置水深 $-20.0 \mathrm{~m}$ と一 $16.0 \mathrm{~m}$ の断面に対する耐用期間中の滑動量および沈下量 の超過出現率である.

滑動量については, 設置水深の相違による超過出現率 の違いが明膫に表れ, 設置水深 $-16.0 m$ の断面の方が出 現率が高くなっている.これは，表一2 を見れば明らか なように, 設置水深 $-20.0 m$ では滑動安全率が 1.26〜 1.35 と許容安全率を大きく上回っているのに対して, 設置水 深- $16.0 m$ では 1.2 以下と許容值を下回っており, 安全裕 度が異なっているためである. 一方, 沈下量については, 設置水深- $20.0 \mathrm{~m}$ の断面の方がやや出現率が高くなって いる. 従来設計法で用いる支持力安全率では差がないに も係わらず沈下量の出現率に差が見られることは, 設置 水深が深い方が堤体の安定性に対して厳しい条件である ことを示している.

図一8 は滑動と沈下の被災レベルと耐波性能の関係を 示したものである.

被災レベルは, 被災の実績や解析手法の精度ならびに 被災時の挙動評価などにより設定すべきであるが，ここ では，健全，機能保持，長期機能喪失回避の 3 段階の耐 波性能に応じた滑動, 沈下の変形量と変形量から決まる 各々の復旧費用の違いを考慮して被災レベルを設定した. また, 被災レベル 4 は防波堤の機能損失レベルとし, 滑 動は基礎捨石マウンドから堤体が転倒する限界として $10.0 \mathrm{~m}$ 以上，沈下は沈下による防波堤の転倒の有無や港 内静穏度の悪化などを考慮して $2.0 \mathrm{~m}$ 以上とした.

図一9および図一 10 は, 設置水深 $-20.0 \mathrm{~m}$ と $-16.0 \mathrm{~m}$ の 断面に対する滑動と沈下の性能レベルに応じた複合出現

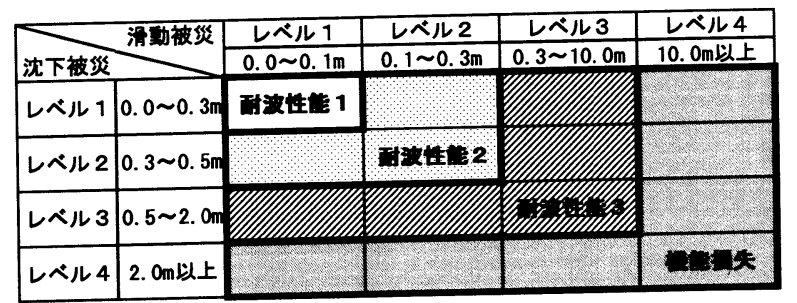

図一8 被災レベルと耐波性能との関係
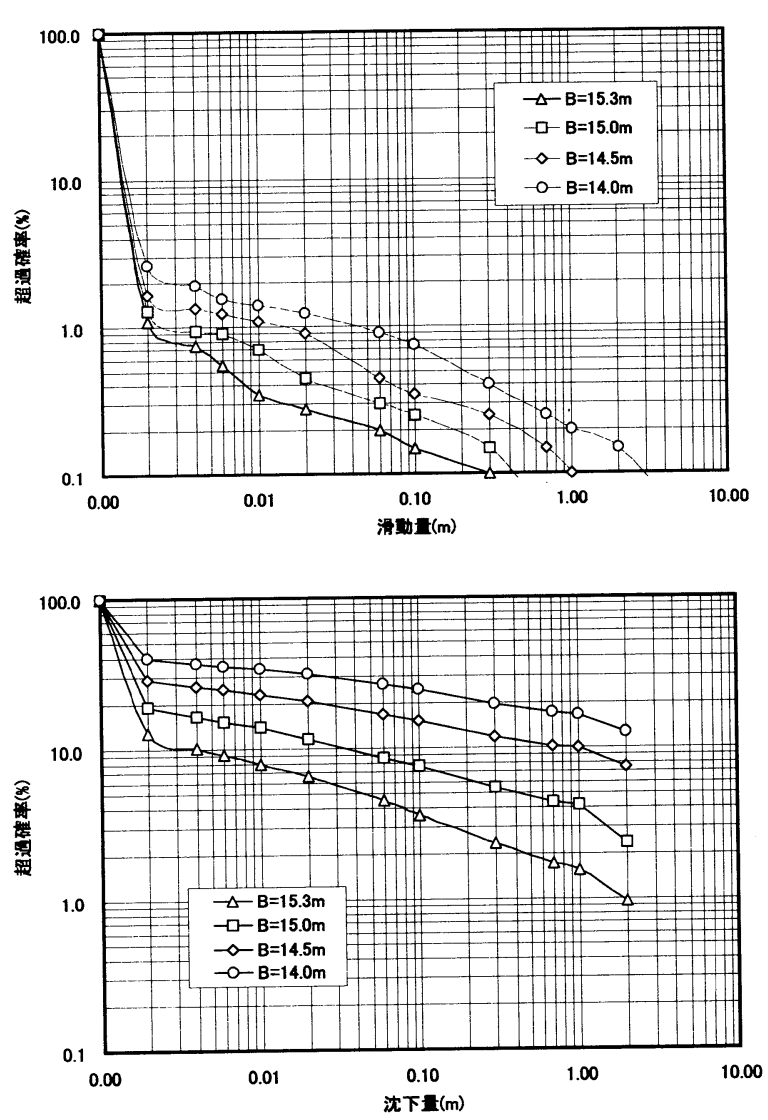

図ー6 滑動量と沈下量の超過出現率 (設置水深-20.0m)
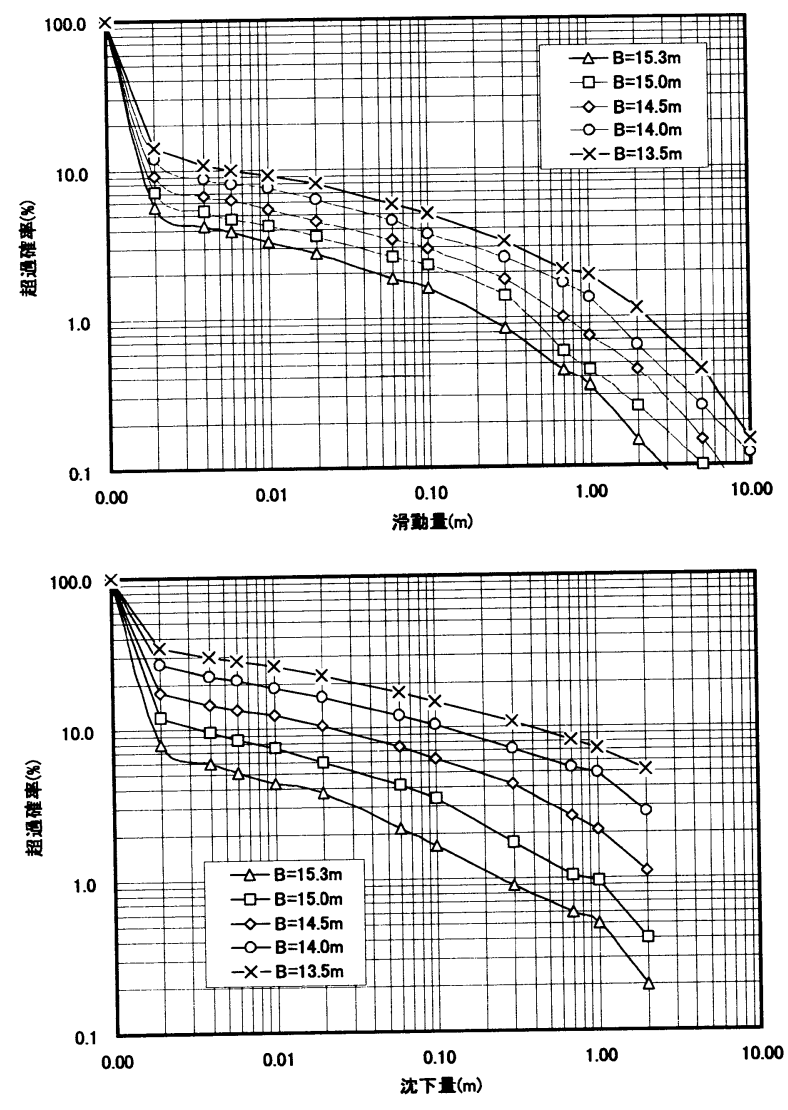

図ー7 滑動量と沈下量の超過出現率 (設置水深- $16.0 \mathrm{~m}$ ) 


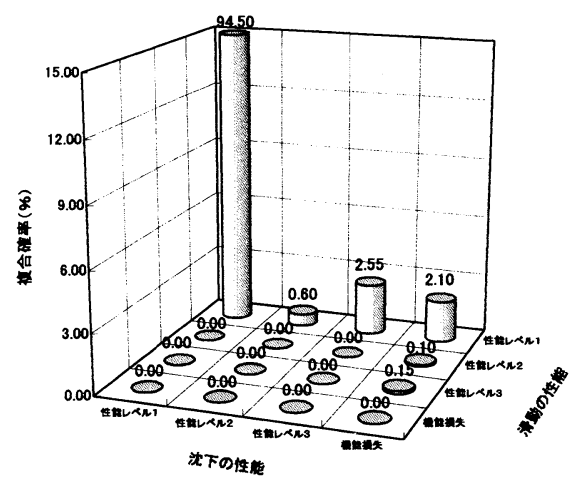

図一9 滑動と沈下の複合出現頻度分布の一例 (設置水深-20.0m，ケース S20-2)

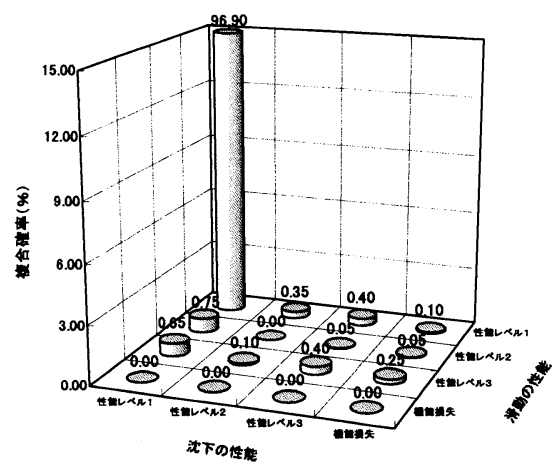

図-10 滑動と沈下の複合出現頻度分布の一例 (設置水深- $16.0 \mathrm{~m}$ ，ケース $\mathrm{S} 16-2$ )

頻度分布の一例である.ここで，滑動と沈下の性能レべ ルは図-8 を適用した．また，例示したケースは，設置 水深は違うものの従来設計法での支持力安全率はほぼ同 じ断面である.

これによれば, いずれのケースも滑動と沈下ともに性 能レベル 1 となるレベルの出現確率が約 $95 \%$ 以上と高 い. また, 設置水深一20.0m のケースでは沈下の性能レ ベル 3 , 機能損失レベルの出現頻度が, 設置水深 $-16.0 m$ のケースでは滑動の性能レベル 2,3 の出現頻度がやや 高くなっており, 設置水深によって堤体の変形特性が異 なっていることがわかる.

\section{4. 直立ヶーソン堤との比較による 半没水上部斜面ケーソン堤の安全性の評価}

先に述べた防波堤の 3 つの安全性評価指標を適用して, 前項で試計算を行った半没水上部斜面ケーソン堤の安全 性を評価し，既に著者ら ${ }^{3}$ )が検討した同条件（設置水深 は一-20.0m) での直立ケーソン堤の安全性評価結果との比 較を行った.

表 -3 は半没水上部斜面ケーソン堤 2 タイプ, 直立ケ ーソン堤 1 タイプ,合計 14 ケースの断面に対する各安全 性評価指標での評価結果である. 表中の網掛けは，各評 価指標で許容值を満たすケース（ライフサイクルコスト については最経済断面）を示している. ここで，ライフ
表ー3 各安全性評価指標での評価結果

【半没水上部斜面ケーソン堤／設置水深 : $-16.0 \mathrm{~m}$ 】

\begin{tabular}{|c|c|c|c|c|}
\hline ケース & 期待滑動量 & 期待沈下量 & 機能損失確率 & L C C (千円) \\
\hline S16-1 & $1.3 \mathrm{~cm}$ & $1.5 \mathrm{~cm}$ & $2.00 \times 10^{-3}$ & 13,370 \\
\hline S16-2 & $2.1 \mathrm{~cm}$ & $2.9 \mathrm{~cm}$ & $4.00 \times 10^{-3}$ & 13,320 \\
\hline S16-3 & $3.3 \mathrm{~cm}$ & $6.5 \mathrm{~cm}$ & $1.10 \times 10^{-2}$ & 13,380 \\
\hline S16-4 & $5.8 \mathrm{~cm}$ & $13.7 \mathrm{~cm}$ & $2.70 \times 10^{-2}$ & 13,670 \\
\hline S16-5 & $9.0 \mathrm{~cm}$ & $23.8 \mathrm{~cm}$ & $5.10 \times 10^{-2}$ & 14,130 \\
\hline \multicolumn{5}{|c|}{ 【半没水上部斜面ケーソン堤／設置水深 : $-20.0 \mathrm{~m} 】$} \\
\hline ケース & 期待滑動量 & 期待沈下量 & 機能損失確率 & L C C (千円) \\
\hline S20-1 & $0.1 \mathrm{~cm}$ & $4.1 \mathrm{~cm}$ & $9.50 \times 10^{-3}$ & 12,700 \\
\hline S20-2 & $0.1 \mathrm{~cm}$ & $9.7 \mathrm{~cm}$ & $2.35 \times 10^{-2}$ & 12,960 \\
\hline S20-3 & $0.3 \mathrm{~cm}$ & $23.5 \mathrm{~cm}$ & $7.55 \times 10^{-2}$ & 14,050 \\
\hline $\mathrm{S} 20-4$ & $0.8 \mathrm{~cm}$ & $39.5 \mathrm{~cm}$ & $1.25 \times 10^{-1}$ & 15,080 \\
\hline \multicolumn{5}{|c|}{ 【直立ケーソン堤／設置水深 : $-20.0 \mathrm{~m} 】$} \\
\hline ケース & 期待滑動量 & 期待沈下量 & 機能損失確率 & $\bar{L}$ C C(千円) \\
\hline V20-1 & $3.2 \mathrm{~cm}$ & $0.8 \mathrm{~cm}$ & $5.00 \times 10^{-4}$ & 15,150 \\
\hline V20-2 & $7.6 \mathrm{~cm}$ & $4.9 \mathrm{~cm}$ & $3.50 \times 10^{-3}$ & 15,000 \\
\hline V20-3 & $12.6 \mathrm{~cm}$ & $12.9 \mathrm{~cm}$ & $710 \times 10^{3}$ & 14,930 \\
\hline V20-4 & $21.4 \mathrm{~cm}$ & $36.5 \mathrm{~cm}$ & $1.19 \times 10^{-2}$ & 14,970 \\
\hline V20-5 & $34.8 \mathrm{~cm}$ & $49.5 \mathrm{~cm}$ & $2.53 \times 10^{-1}$ & 15,190 \\
\hline
\end{tabular}
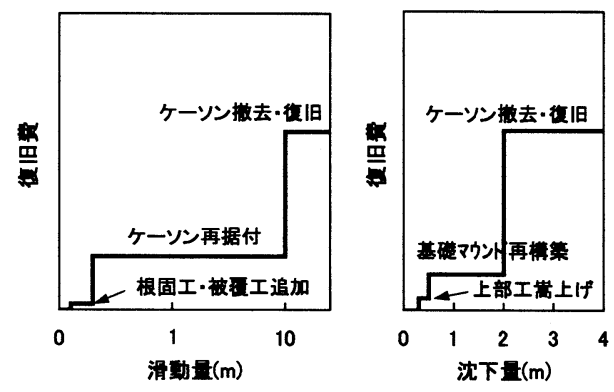

図ー11 被災レベルと復旧費の関倸

サイクルコストの検討では，各被災レベルと復旧費の関 係を図一11 のようにした. 図一 12 は各ケースのライフサ イクルコストにおける総工事費，初期建設費，災害復旧 費を示したものである.

既に検討した直立ケーソン堤では，いずれの評価方法 を用いても，最適断面としてほぼ同程度の堤体幅が与え られる. しかしながら，半没水上部斜面ケーソン堤では， 評価方法によって最適断面が異なる傾向が見られる.

詳細に分析すると，設置水深 $-20.0 \mathrm{~m}$ では，機能損失確 率による評価とライフサイクルコストによる評価では S20-1 のケースが最適断面とされるが，期待滑動・沈下 量による評価では S20-4 のケースでも許容值を大きく下 回り十分な安全裕度がある評価となっている．設置水深 $-16.0 m$ でも同様の傾向を示し, 機能損失確率による評 価とライフサイクルコストによる評価では S16-2 のケー スが最適断面とされるが，期待滑動・沈下量による評価 では S16-5 のケースでも十分な安全裕度がある評価とな っている.

機能損失確率による評価とライフサイクルコストに よる評価が最適断面として同じ断面を与えるのは, ライ 


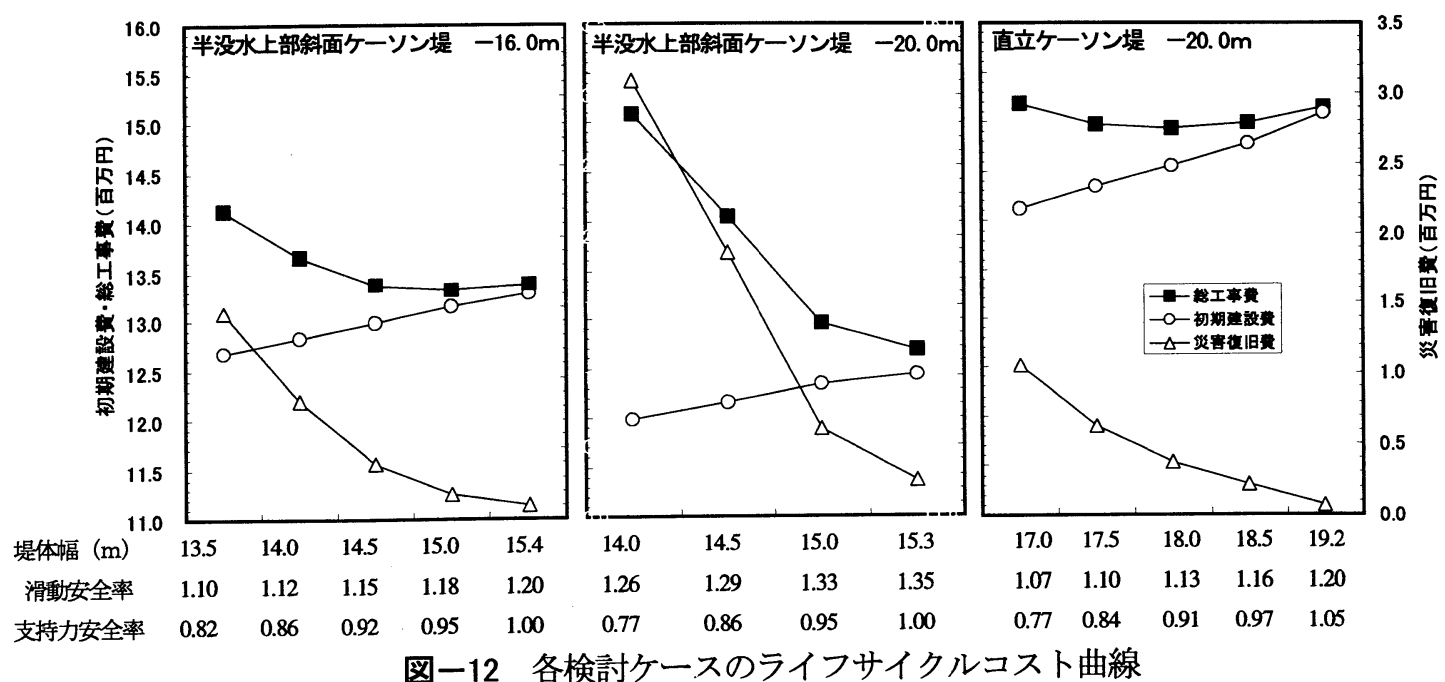

フサイクルコストにおける災害復旧費に占める機能損失 レベルの復旧費が大きいためであり，防波堤の壊滅的な 被害の発生確率をある程度抑制することがトータルコス トの低減につながるものと考えられる.一方, 期待滑動・ 沈下量による評価では，提案した許容值を用いると大幅 な断面縮小が図れるが, ライフサイクルコストでは現行 設計法による断面よりも不経済となる．また，直立ケー ソン堤と比較すると, 半没水上部斜面ケーソン堤の期待 滑動量, 沈下量は非常に小さく, 耐波性能 1，2 に対して は機能的に優れていると考えられる。

以上のように，半没水上部斜面ケーソン堤では，直立 ケーソン堤と異なり，3 つの評価方法によって与えられ る最適断面が異なる傾向が見られ，変形量による評価よ りもむしろ機能損失確率による評価やライフサイクルコ ストによる評価が重要であると考えられる.

\section{5. まとめ}

本論文は，防波堤の性能設計活用による設計合理化の 一環として, 経済的な防波堤である半没水上部斜面ケー ソン堤への適用について検討したものである.

これより以下の結果が得られた.

(1) 既に提案した直立ケーソン堤に対する滑動・沈下量 算定方法を拡張して, 半没水上部斜面ケーソン堤の滑 動・沈下量の算定方法を提案した.

(2) 半没水上部斜面ケーソン堤の滑動量, 沈下量は, 設 置水深によって変形量の出現特性が異なり, 設置水深 $-20.0 m$ では沈下が, $-16.0 m$ では滑動が支配的となる.

(3) 防波堤の $3 つ の$ 安全性評価指標を適用すると, 半没 水上部斜面ケーソン堤では, 期待変形量による評価結 果と機能損失確率による評価結果ならびにライフサ イクルコストによる評価結果とで, 与えられる最適断 面が異なる傾向が見られた.

(4) 半没水上部斜面ケーソン堤は, 直立ケーソン堤に比 心゙ると期待滑動・沈下量は小さく, 而波性能 1,2 に 対しては機能的に優れている.
（5）防波堤の変形挙動を考慮した設計法を用いることに より, 従来の破壊安全率で評価できなかった滑動と沈 下の相互作用や構造様式の違いによる耐波安定性の 相違も評価できることが明らかとなった.

（6) 防波堤の経済性評価を重要視するならば，防波堤の 壊滅的な被害の発生確率である機能損失確率をある 程度抑制することが必要である.

今後は，本研究成果の実務への適用を図るとともに， より簡便に断面設定ができる簡易設計法を構筑していく 予定である. また，港湾・海岸施設において最適な防災 水準を設定する手法の一つとして適用検討を実施してい きたい.

\section{参考文献}

1) 下迫健一郎・高橋重雄 : 期待滑動量を用いた混成防波 堤直立部の信頼性設計法, 港湾技術研究所報告, 第 37 巻, 第3 号, pp.3-30, 1998.

2) 土田孝・湯怡新 : 港湾構造物の円弧すべり解析におけ る最適な安全率, 港湾技術研究所報告, 第 35 巻, 第 1 岇, pp.117-145, 1996.

3) 興野俊也・赤石沢総光 - 阿部光信 - 長舩徹 : 性能設計 活用による防波堤の設計合理化について, 海岸工学論 文集, 第 47 巻, pp.816-820, 2000.

4)長尾毅 : 防波堤の全体系安全性のレベル 1, レベル 2 の信頼性設計, 港湾構造物設計事例集, 第 3 編, pp.15-36, 1999.

5) 細山田得三・高橋重雄・谷本勝利 : 離島港湾における 上部斜面堤の適用性について, 海岸工学論文集, 第 41 巻, pp.706-710, 1994.

6) 谷本勝利・古川浩司・中村廣昭 : 混成堤直立部の滑動 時の流体抵抗力と滑動量算定モデル, 海岸工学論文集, 第 43 巻, pp.846-850, 1996.

7) 阿部光信 - 興野俊也・長舩徹 - 貝沼憲男 : 防波堤の信 頼性設計法における時化のモデル化について, 海岸工 学論文集, 第 46 巻, pp.916-920, 1999. 